\title{
Derivatives as Technological Disruption: A Conceptual Approach on Complex Global Financial Instrument Innovation and Related Tax Policy Tool Responses
}

\author{
Jasper Kim \\ Graduate School of International Studies and Law School, Ewha Womans University, Seoul, South Korea
}

Received June 16, 2021; Revised July 23, 2021; Accepted August 22, 2021

\section{Cite This Paper in the following Citation Styles}

(a): [1] Jasper Kim, "Derivatives as Technological Disruption: A Conceptual Approach on Complex Global Financial Instrument Innovation and Related Tax Policy Tool Responses," Universal Journal of Accounting and Finance, Vol. 9 , No. 4, pp. 820 - 827, 2021. DOI: 10.13189/ujaf.2021.090428.

(b): Jasper Kim (2021). Derivatives as Technological Disruption: A Conceptual Approach on Complex Global Financial Instrument Innovation and Related Tax Policy Tool Responses. Universal Journal of Accounting and Finance, 9(4), 820 - 827. DOI: 10.13189/ujaf.2021.090428.

Copyright $\odot 2021$ by authors, all rights reserved. Authors agree that this article remains permanently open access under the terms of the Creative Commons Attribution License 4.0 International License

\begin{abstract}
Derivatives can be embedded in financial engineered structures involving one or more conduit entities and jurisdictions. Increased innovation led to an emergent market view that assets can be both de- and re-composable, with each iteration version being tradable "aspect[s] of assets" in the marketplace. Conceptual methodology of this article provides a conceptual tax policy analysis arguing that derivatives instrument innovation poses several significant challenges to the traditional tax system. Such factors must be carefully weighed by policymakers, given their respective specific market dynamics and tax objectives, leading to the conclusion that not one approach represents a policy panacea to derivatives financial instruments. This article provides a conceptual tax policy analysis arguing that derivatives instrument innovation poses several significant challenges to the traditional global tax system, which has been traditionally predicated on a clear-cut demarcation regarding: (1) asymmetric tax treatment between debt and equity; (2) the timing rule in terms of income recognition for tax purposes (e.g. accrual versus realization); and (3) income characterization (e.g. ordinary income versus capital gains). The conceptual tax policy responses, including anti-avoidance measures, mark-to-market, bifurcation, integration, and various information-sharing regimes, have their benefits and weaknesses.
\end{abstract}

Keywords Financial Derivatives, Financial Innovation, Tax Policy

\section{Introduction}

Derivatives often blur the dividing lines between traditional threshold criteria (i.e., asymmetric tax treatment between debt/equity, accrual versus realization method of income recognition, and income characterization). They are distinguishable financial instrument innovations from traditional plain vanilla financial products, whereby clear-cut delineations exist more readily [1]. The combination of market liberalization and innovation led to the creation of financial derivatives, whereby its price is derived from the price of a separate reference obligation [2]. Derivative products include futures contracts (traded on exchanges), forwards (traded in the OTC market), swaps and options. Such financial tools can be used for either hedging or speculative purposes, worth an estimated $\$ 640$ trillion (as of June 2019) [3]. The more sophisticated and exotic the financial derivative instrument innovation, often the opaquer and more challenging to examine their underlying, constituent components. This phenomenon acutely applies in a broad spectrum of financial instrument innovation from hybrids issued directly between related entities to hybrids/synthetics issued and a series of conduit companies (whereby the hybrid is treated as equity in Conduit Entity 1, and debt in Conduit Entity 2), both 
onshore and offshore, including in tax haven (tax efficient) jurisdictions.

If a tax jurisdiction within the global financial system lacks clear tax policy rules regarding derivatives instrument innovation treatment, then tax base erosion becomes a potential policy problem. Ambiguity allows taxpayers to engage in tax arbitrage, recharacterize income, reconstitute instrument classification, and change income recognition timing explicitly for tax benefits [4], without changing the substantive economic nature of the financial instrument [5].

From a global financial order purview, a system of competition and lack of coordination exists regarding the exact tax treatment of derivatives in an international, cross-border context. Tax treatment of derivatives are not unified. As such, capital flows derived from derivatives are often dictated by different and disparate tax rules, based on a function of treaty provisions related to the type and character of such capital flows [6].

What allows for such problems to arise? One issue is an outdated assumption that all financial products could be clearly bifurcated into debt or equity [7]. For example, when it comes to debt treatment, interest payments are generally deductible as an expense for the issuer; however, return to equity (dividends) generally does not receive such treatment $[8,9]$. Another example is when interest (debt treatment) is generally taxed on an accrual basis, whereas dividends (equity treatment) are taxed on a realization basis [10,11]. And finally, dividends are often taxed as ordinary income only when realized (in contrast to interest payments) and generally taxed at a lower capital gains tax rate [12].

As a case in point, a financial transaction is taken where derivatives are used by a firm to invest in a foreign subsidiary (assuming the home country uses a territorial tax system). If the investment is equity financed, no tax deduction is generally given, and no tax obligation exists in the home country. In contrast, if the investment is financed in the form of a loan (debt, not equity), then the loan payments are often treated as tax deductible in the host country and taxable in the home country. A separate case is also considered where the home country is now operated under a worldwide tax regime (e.g., U.S.). Even in this instance, hybrid financing remains the dominant structuring strategy in a prisoner's dilemma context [13] since derivatives often allow for deductibility in the host country with a tax credit in the home country (for corporate tax obligations in the host country) [14].

In another transnational conceptual case, a transaction is considered whereby U.S. tax rules that consider several criteria to determine whether a financial instrument should be characterized as debt or equity, compared to the French tax system that primarily considers one variable, voting rights, to make such debt or equity characterization. Here, tax arbitrage opportunities exist in a cross-border transaction. If a conceptual entity, US1, makes an investment into France with an instrument that resembles equity in all aspects but does not confer voting rights, the instrument will likely be characterized, first, as equity from the U.S. tax perspective, and second, as debt from France's tax perspective. Such tax avoidance opportunities, which effectively lower tax rates on investments, are possible since each country happens to emphasize different criteria in their financial instrument debt versus equity characterization calculus [15]. In certain cases, such tax arbitrage opportunities have led to significant tax losses in the billions [16].

\section{Method}

The methodology of this article provides a conceptual tax policy analysis arguing that derivatives instrument innovation poses several significant challenges to the traditional global tax system, which has been traditionally predicated on a clear-cut demarcation regarding: (1) asymmetric tax treatment between debt and equity; (2) the timing rule in terms of income recognition for tax purposes (e.g. accrual versus realization); and (3) income characterization (e.g. ordinary income versus capital gains). The conceptual tax policy responses, including anti-avoidance measures, mark-to-market, bifurcation, integration, and various information-sharing regimes, have their benefits and weaknesses. Such factors must be carefully weighed by policymakers, given their respective specific market dynamics and tax objectives, leading to the conclusion that not one approach represents a policy panacea to derivatives financial instruments.

\section{Results (Conceptual Analysis)}

Derivatives can be embedded in financial engineered structures involving one or more conduit entities and jurisdictions. Increased innovation led to an emergent market view that assets can be both de- and re-composable, with each iteration version being tradable "aspect[s] of assets" in the marketplace. In the value-maximizing pursuit of deriving optimal value in both de- and re-composable form, each asset was further parsed into ever-thin slices in terms of the potential to decouple and recouple economic, voting, and other rights typically associated with assets.

This phenomenon served as requisite pretext for the genesis and subsequent big bang of financial derivatives, which in turn, created opportunities to hedge risk across jurisdictions, including tax-efficient jurisdictions to capitalize on tax arbitrage opportunities at a global scale, often in programme structures (involving MTN note programmes with CDSs, FX swaps, and SPVs) that, as Wigan argues, did not incentivize full disclosure [17]. In certain case that is similar to the above example but with one or more conduit entities, the home country firm 
investing in a foreign country can achieve equity treatment, and debt treatment in the host country [18]. Conduit entities allow firms to exploit debt-equity demarcation rules between not just the home and host jurisdictions, but also in third-party jurisdictions [19].

The following conceptual transaction is considered: two products exist, one plain vanilla (baseline case) and the other a hybrid derivatives instrument (coming, debt, equity, and potentially other derivatives), with each/both returning the same cashflows, but each receiving asymmetric tax treatment, which allows and invites tax arbitrage when using derivatives [20]. The first product, a bond with a forward contract, would have its bond coupons taxed each year as ordinary income, and the capital gains/losses from the forward contract would be taxed on settlement date of the contract. However, the hybrid derivative product involving a structured note (contingent debt) is unclear, since debt yield of the product in each period cannot be calculated until its final payment $[21,22]$. If the taxpayer delays the tax point until the entire product is closed, a substantial deferral of tax liabilities would ensue, unlike with the first plain vanilla product (baseline case) example, even though both their economic substance is similar.

Traditional tax regimes and policymakers also face challenges in characterizing synthetic instruments (structured from several instruments to replicate and synthesize the cashflows of another financial instrument, with options and forward contracts as examples of synthetic instruments) since taxpayers could structure in form one financial instrument into another for tax arbitrage benefit [23]. For instance, an investor holding a share that has substantially gained value, and is interested in selling the share for a bond, could defer capital gains realization by creating a synthetic bond with a short forward contract. Here, the net effect is that the contract price synthetically replicates that of the bond principal. By doing this, capital gains (from selling the share), and the interest income (from the bond) are both deferred until the forward contract expires [24, 25].

Another potential tax system challenge with synthetics is the ability of taxpayers to strategically realize losses of some components without realizing the offsetting gains in other components at any given time series [26]. For example, with the same earlier example, if the taxpayer could choose to close out the contract and hold onto the share (in lieu of waiting for the contract to mature), a loss would be realized on the forward contract, without realizing accrued gain of the share in the same time series. This allows the taxpayer to receive substantial tax arbitrage benefits from the deferred recognition of the gains made [27].

\section{Policy Discussion}

A challenge in taxing derivatives exists in the form of the traditional tax system's asymmetric treatment of economically equivalent cashflows [28]. Given this, investors can exploit such asymmetric tax treatment by using derivatives to receive beneficial (artificial) tax benefits [29]. The posited solution must also be able to address how derivatives are used, as such, regarding both a specific and continuous time series.

Various countries have tried different methods to deal with the tax challenge related to derivative products [30]. Some of the more interesting tax policy option approaches include integration, birfurcation, mark-to-market, withholding tax on payments to nonresidents, and income (including premium) classification methods when applying a tax treaty.

\section{Integration}

The integration approach involves the derivative in question being linked to other related financial instruments and taxes them as a composite (wholly combined). Take a perfect hedge (long position) as an example, taxpayers would normally benefit by realizing losses. Here, the integration method would deny loss realization until both the call and put positions are terminated. This could be taken further still to defer any tax benefit until the underlying hedged asset itself is also terminated.

An argument against using the integration approach is the immense difficulty in linking the derivative in question to its linked transactions (onshore and/or offshore), which in practice, could be administratively impracticable if not at times impossible [31]. Such challenge would be particularly acute in the case of hybrids and synthetics using conduit vehicles in offshore, tax-efficient (e.g., tax havens or tax secrecy) jurisdictions [32].

\section{Bifurcation}

The bifurcation method of taxing derivatives is developed based on the assumption that derivatives are a function of separate but related composite components [33, 34] (e.g., a contingent debt obligation composed of a standard fixed-interest debt instrument attached to a long-position forward contract). Under the bifurcation method, each component would be taxed (bifurcated) as separate instruments, and hence, in theory at least mitigating incentives to enter derivatives for primarily tax arbitrage benefits. Another benefit is that bifurcation would work under most traditional tax regimes due to the separation of asset classification (i.e., debt and equity).

Two arguments exist against using the bifurcation method. The first is that the composition of financial products to form derivatives is a value-added feature in the marketplace (for hedging and/or speculative purposes, akin to the value-added of putting separate components together to form an autonomous-driving vehicle). The second argument is that the decomposition of derivatives 
into its more foundational composite components can exist at more than one level [35], thus raising the question of what level to pierce through in every transaction, in every market, and in every instance. A fixed-to-floating rate swap, for instance, could be bifurcated into either a series of forwards or fixed-floating rate debt obligations.

\section{Retrospective Taxation}

An alternative to the above approaches exists by way of retrospective taxation. This approach essentially taxes only the risk-free rate of return from holding an asset. Here, the actual gain/loss of the risk-free rate (i.e., the risk premium amount) is untaxed [36]. Given this, in theory, no taxpayer incentive exists for tax arbitrage, either at a specific or continuous time series when held.

The benefit of retrospective tax is that neither the (derivative) asset acquisition cost nor cost basis adjustment (as in the mark-to-market approach) is required [37, 38]. The conceptual basis for the approach is based on the notion that the risk-adjusted tax liability on the risk premium should be net zero, since income tax reduces both net tax gains and losses (assuming tax losses are deductible). A weakness is that the retrospective taxation approach may be administratively burdensome, while requiring large-scale market coordination and information sharing [39].

\section{Mark-to-Market}

Derivatives product valuation can be opaque and notably fluctuate, which makes taxing derivatives challenging, particularly under a traditional tax regime [40]. One possible solution is utilizing a mark-to-market approach, whereby for tax purposes, the gain/loss (calculated as the differential between the derivatives' market value and cost basis) would be recognized by the asset holder (at the end of a specified tax period, as it was sold) [41]. From a cost basis perspective, the derivative instrument would be adjusted (as a gain or less). The benefit of the mark-to-market method for taxing derivatives is that it applies the same tax rate to both market-based gains and losses (i.e. symmetric tax treatment) at a specific time series, which mitigates the timing variable related to income recognition (when mark-to-market is not used) [42].

Although the practice of using mark-to-market is now relatively common, and the benefits exist, countervailing forces in terms of weaknesses exist. One weakness is evidenced when derivatives (as OTC products) have few or no market comparable (i.e. for thinly traded markets, or derivatives under financial stress, as seen in the 2007/08 financial crisis) [43]. As such, tax arbitrage opportunities could resurface in dual, co-existing tax "parallel universes" whereby in one market (universe) financial derivatives are marked-to-market, while in another market (universe), derivatives are not marked-to-market.

An additional weakness in the global system exists in a scenario when unrealized gains face a tax burden (when normally, without a mark-to-market, no tax burden would ensue), which in turn, causes a cashflow problem if the gains are not ultimately realized. As a conceptual example, if a CDS (credit default swap) is held for hedging (rather than speculative) purposes to create a so-called "perfect hedge". Then, generally, there would be no net gain when the (perfect hedge) position is closed out on the underlying asset [46]. However, a tax liability could exist if the CDS is marked to market but the asset being hedged (e.g., structured note) is not marked to market. Finally, another weakness of using mark-to-market is its incongruity with aspects of the traditional tax system, such as the asymmetric tax treatment of debt and equity, and of ordinary income compared to capital gains. Certain rules would need to be instituted to resolve such tax policy incongruities. For example, in the U.S. case, trading futures gains/losses are treated as capital, while for non-corporate taxpayers, they are subject to the so-called "60/40 rule" that is not dependent on time period. Moreover, for hedging transactions, gains/losses are recognized only when their related trading positions are closed out on the hedged assets [46].

\section{Selecting a Derivatives Taxation Policy}

Based on a single approach all the time, in all markets to tax derivatives is inherently difficult. As such, a "one-size-fits-all" tax policy approach, albeit elegant, may not always be a sound approach due to its inflexibility and disregard for the particular market conditions in which the tax policy approach is being implemented. As previously argued, each method has its strengths and weaknesses.

The mark-to-market approach could be effective for widely-traded derivatives with many comparables, with accounting systems based on the mark-to-market principle. The bifurcation and integration methods, although conceptually opposite, could coexist and be applied based on a transactional case-by-case application, which is the practice of many OECD countries. Meanwhile, retrospective taxation (as argued for by Auerbach and Bradford) is theoretically elegant, but administrative (and perhaps politically) challenging [47]. Thus, one tax policy approach would be to allow each tax jurisdiction to decide independently, by which those outlined would be the most effective (or least ineffective) in a particular case. Admittedly, this in turn, could potentially lead to incongruous derivatives-related regulatory regime "wrinkles" in a particularly region and/or globally.

\section{Anti-Avoidance Measures as a Tax Regulation Policy for Derivatives}

If derivatives are used as a tax arbitrage tool leading to tax avoidance, why has more effective anti-avoidance measures not been used? Take, as one seemingly straightforward conceptual anti-avoidance measure, a host country requiring conditional dividend exemption on 
non-deductibility in the host country. Effective as it seems, such anti-avoidance measure exists in only a few jurisdictions [48]. But to effectively tax hybrid structures using derivatives, anti-avoidance rules must pierce through the often opaque and complex chain of offshore conduit entities to determine whether, for instance, dividend income is ultimately derived from a deductible payment by a subsidiary, or from a non-deductible payment from another source [49].

Anti-avoidance regulations could also be put in place to allow tax authorities to recharacterize derivatives [50], such as those involving multiple conduits, treated instead for tax purposes, as transactions directly between two entities. CFC (Controlled Foreign Corporation) rules could also be enacted so that home jurisdictions can treat foreign subsidiaries in low-tax jurisdictions as domestic (onshore) subsidiaries for tax purposes [51]. Further, withholding taxes on dividend and interest payments to tax havens could also be implemented, but this begs the question of how to define a so-called "tax haven."

What about a coordinated global on hybrid-derivatives? In Europe, DAC 1 and 2 regimes (DAC 1 2011/16/EU, DAC 2 2014/107/EU) for administrative cooperation in conjunction with a DOTAS-like regime (where tax regulators receive derivatives transaction-related details directly from the taxpayer) could also be utilized. The tradeoff, under a bounded optimality model, would be the need for greater resources and coordination (for derivatives information-sharing), which requires the insertion of yet another regulatory layer that potentially increases complexity and market distortions [53, 54].

The rise of derivatives instrument innovation provided a policy lesson that due to apparent asymmetries, regulators were unable, and to a certain extent, unwilling to coordinate and share information. Since the 1980s, European and global financial markets have increased exponentially in terms of size, savvy, and scope. As Helleiner and Ryner argue, the liberalization of financial markets and the removal of capital controls and flows has reconstituted the relationship dynamics between not just the financial sector and the nation-state, but at another dimension in the strategic multi- dimensional chessboard, the financial sector, and its participants with market regulators $[55,56]$. An output function of such financial market exponential size, savvy, and scope, as argued by Wigan and others, is financial market innovation, which in turn, led to financial product sophistication, namely financial derivatives (above and beyond mere "plain vanilla" products) such as swaps, options, and futures, whereby the value of the product is a function of a separate referenced obligation (to use ISDA definitions) $[57,58]$.

This then raises the question: "why not have all tax jurisdictions simply cooperate?" Although benefits from global coordination regarding tax policy seems obvious on its face, Johannesen's model-based research suggests that an "uncoordinated policy equilibrium" exists at the global level [59], in which countries do not adequately utilize anti-avoidance measures, while multinational entities use hybrids and derivatives in tax avoidance schemes, leading to countries "optimally" and allowing for tax avoidance $[60,61]$. Such findings are also a function of firms using immobile factor production inputs. Other tax policy suggestions also exist, including regarding transfer pricing rules, thin capitalization rules, and taxation of capital flows to tax havens.

Somewhat more controversially, a Financial Transaction Tax (FTT) could also be a possible tax policy feature, which includes and captures derivatives, to work in conjunction with other measures, such as anti-money laundering (AML) initiatives and treaty-based mutual assistance agreements for tax matters. The FTT, as background, is a European Commission proposal, initially introduced in 2011, to enact a financial transaction tax within certain EU member states. The FTT, separate from a bank levy and/or banker bonus tax, has the objectives of (1) mitigating against the costs of future bank crises and bailouts; and (2) raising up to 57 billion Euros per enacted year. In concept, FTT would be imposed on financial transactions between financial institutions based on financial product type, specifically levying a tax of $0.1 \%$ applied to debt and equity transactions, and $0.01 \%$ applied to financial derivatives transactions.

However, because FTT provisions typically tax derivatives at a much lower rate than debt or equity transactions [62], this could incentivize financial engineering of investments into derivatives products. This, in turn, could spur, not inhibit, the use of multiple, relatively opaque conduit vehicles, making tracking and information sharing even more challenging, particularly outside the FTT's jurisdiction, above and beyond raising both capital (that can correlate with innovation) [63] and transaction costs [64]. Moreover, if used, FTT should retain a residence capturing principle so that tax is due to relevant party (or beneficial owner). At a practical level, some scholars have argued for an ISDA agreement amendment to reflect that any FTT tax on derivatives that are unpaid are subsequently deemed null and void [65]. The ISDA amendment approach could create an effective mechanism for global compliance, whereas without it, an incentive would exist to structure derivatives transactions outside FTT's scope and jurisdiction.

\section{Conclusions}

This conceptual article argues that financial derivatives instrument innovation poses several significant challenges to the traditional tax system at the global level, which have been historically predicated on a clear-cut demarcation related to asymmetric tax treatment between debt and equity, the timing rule in terms of income 
recognition for tax purposes (e.g., accrual versus realization) and income characterization. Tax authorities globally were grossly out-resourced, outdated, and outmaneuvered when it came to understanding and dealing with tax arbitrage transactions involving derivatives instrument innovations in multiple jurisdictions, time horizons, and legal regimes. The tax policy responses outlined in this article, including mark-to-market, bifurcation, integration, anti-avoidance measures, and information-sharing regimes, have their benefits and weaknesses, which must be carefully weighed by policymakers, given their respective specific market dynamics and tax objectives, leading to the conclusion that not one approach represents a policy panacea to derivatives financial instrument innovation.

\section{Conflict of Interest}

No conflict of interest exists.

\section{REFERENCES}

[1] Vella J., "The Asymmetrical Treatment of Debt and Equity Under UK Tax Law" [2011] in Arad Reisberg and Dan Prentice (eds), Corporate Finance Law: UK and EU Perspectives, Oxford University Press, pp. 361-392, 2011.

[2] ISDA, "ISDA Credit Derivatives Definitions," pp. 12-15, 2014.

[3] BIS, "BIS Statistical Release: OTC Derivatives statistics at end-June 2019,” BIS Publishing, pp. 1-8, 2019.

[4] Donohoe, M., "Financial Derivatives in Corporate Tax Avoidance: A Conceptual Perspective," Journal of American Accounting Association, vol. 1, no.38, pp. 35-37, 2015. https://www.elibrary.imf.org/downloadpdf/books/07 1/06744-9781589063167-en/06744-9781589063167-en-bo ok.pdf

[5] Zee H., "Taxing the Financial Sector: Concepts, Issues and Practice," IMF Paper, pp. 45-56, 2004.DOI: https://doi.org/10.5089/9781589063167.071

[6] Donohoe M., "Financial Derivatives in Corporate Tax Avoidance: A Conceptual Perspective," Journal of American Accounting Association, vol. 1, no.38, pp. 35-37, 2015. https://www.elibrary.imf.org/downloadpdf/books/07 1/06744-9781589063167-en/06744-9781589063167-en-bo ok.pdf

[7] Johannesen N., "Tax avoidance with cross-border hybrid instruments," [2014] Journal of Public Economics, vol. 112, pp. 40-52, 2014. DOI: 10.1016/j.jpubeco.2014.01.011

[8] Desai M., Foley F.., Hines J, "A multinational perspective on capital structure choice and internal capital markets" Journal of Finance, vol. 59, no. 6, 2004. DOI: 10.1111/j.1540-6261.2004.00706.x

[9] Huizinga H., Leaven L., Nicodeme G., "Capital structure and international debt shifting," Journal of Financial Economics, vol. 88, no. 1, pp. 80-118, 2008

[10] Kleven H. J., Slemrod J., "A Characteristics Approach to Optimal Taxation and Tax-Driven Product Innovation," Working Paper, University of Michigan, 2009.

[11] Lewellen K., Robinson L., "Internal Ownership Structures of U.S. Multinational Firms" SSRN, 2013.

[12] OECD, "Hybrid Mismatch Arrangements: Tax Policy and Compliance Issues," OECD Publishing, pp. 1-27, 2012. https://www.oecd.org/ctp/aggressive/HYBRIDS_ENG_Fin al_October2012.pdf

[13] Dagan T., "International Tax Policy: Between Competition and Cooperation," Cambridge University Press, 2018.

[14] Warren A. C., "The Corporate Interest Deduction: A Policy Evaluation," Yale Law Journal, vol. 83, pp. 1585, 1974. DOI: $10.2307 / 795548$

[15] Krahmal A, "International hybrid instruments: jurisdiction dependent characteristics," University of Houston Tax Law Journal, pp. 98-127, 2005.

[16] OECD, "Hybrid Mismatch Arrangements: Tax Policy and Compliance Issues," OECD Publishing, pp. 1-27, 2012. https://www.oecd.org/ctp/aggressive/HYBRIDS_ENG_Fin al_October2012.pdf

[17] Wigan D., "Financialisation and Derivatives: Constructing an Artifice of Indifference," Competition and Change, pp. 157-172, 2009. DOI: 10.1179/102452909X417033

[18] Mills L., Newberry K., "Firms' off-balance sheet and hybrid debt financing: evidence from their book-tax reporting differences," Journal of Accounting Res, vol. 43, no. 2, pp. 251-282, 2005. DOI: 10.1111/j.1475-679x.2005.00170.x

[19] Johannesen N., "Tax avoidance with cross-border hybrid instruments," [2014] Journal of Public Economics, vol. 112, pp. 40-52, 2014. DOI: 10.1016/j.jpubeco.2014.01.011

[20] Krahmal A., "International hybrid instruments: jurisdiction dependent characteristics," University of Houston Tax Law Journal, pp. 98-127, 2005.

[21] Johannesen N., "Strategic line drawing between debt and equity," EPRU Working Paper, no. 4, pp. 3-38, 2011 https://www.econstor.eu/bitstream/10419/82109/1/wp-1104.pdf

[22] Johannesen N., "Strategic line drawing between debt and equity," EPRU Working Paper, no. 4, pp. 3-38, 2011. https://www.econstor.eu/bitstream/10419/82109/1/wp-1104.pdf

[23] Engel E., Erickson M., Maydew E., "Debt-equity hybrid securities," Journal of Accounting Res., vol. 37, no. 2, pp. 249-274, 1999. DOI: 10.2307/2491409

[24] Zee H., "Taxing the Financial Sector: Concepts, Issues and Practice," IMF Paper, pp. 1-93, 2004. DOI: 10.5089/9781589063167.071

[25] Donohoe, M., "Financial Derivatives in Corporate Tax Avoidance: A Conceptual Perspective," Journal of American Accounting Association, vol. 1, no.38, pp. 35-37, 2015. 
https://www.elibrary.imf.org/downloadpdf/books/071/067 44-9781589063167-en/06744-9781589063167-en-book.pd $\mathrm{f}$

[26] Keen M., De Mooij R., "Debt, taxes and banks," IMF Working Paper, SP/12/48, 2012.

[27] Mills L. and Newberry K., "Firms' off-balance sheet and hybrid debt financing: evidence from their book-tax reporting differences," Journal of Accounting Res, vol. 43, no. 2, pp. 251-282, 2005. DOI: 10.1111/j.1475-679x.2005. 00170.x

[28] Vella J., "The Asymmetrical Treatment of Debt and Equity Under UK Tax Law" [2011] in Arad Reisberg and Dan Prentice (eds), Corporate Finance Law: UK and EU Perspectives, Oxford University Press, pp. 361-392, 2011.

[29] Vella J., "The Asymmetrical Treatment of Debt and Equity Under UK Tax Law" [2011] in Arad Reisberg and Dan Prentice (eds), Corporate Finance Law: UK and EU Perspectives, Oxford University Press, pp. 361-392, 2011.

[30] OECD, "Hybrid Mismatch Arrangements: Tax Policy and Compliance Issues," OECD Publishing, pp. 1-27, 2012. https://www.oecd.org/ctp/aggressive/HYBRIDS_ENG_Fin al_October2012.pdf

[31] Zee H., "Taxing the Financial Sector: Concepts, Issues and Practice," IMF Paper, pp. 45-56, 2004.DOI: https://doi.org/10.5089/9781589063167.071

[32] Donohoe M., "Financial Derivatives in Corporate Tax Avoidance: A Conceptual Perspective," Journal of American Accounting Association, vol. 1, no.38, pp. 35-37, 2015. https://www.elibrary.imf.org/downloadpdf/books/07 1/06744-9781589063167-en/06744-9781589063167-en-bo ok.pdf

[33] Hasen D., "A Realization-Based Approach to the Taxation of Financial Instruments," Tax Law Review, vol. 57, pp. 398-479, 2003. https://digitalcommons.law.scu.edu/cgi/vie wcontent.cgi? article $=1350 \&$ context $=$ facpubs

[34] Zee H., "Taxing the Financial Sector: Concepts, Issues and Practice," IMF Paper, pp. 45-56, 2004.DOI: https://doi.org/10.5089/9781589063167.071

[35] Laukkanen A., "Taxation of Investment Derivatives," IBFD Publishing, 2007.

[36] Auerbach A., "Retrospective Capital Gains Taxation," NBER Working Paper No. 2792, 2004.

[37] Auerbach A., "Retrospective Capital Gains Taxation," NBER Working Paper No. 2792, 2004. https://www.nber.org/reporter/spring04/taxpayer-behaviorand-government-policy

[38] Auerbach A., "Retrospective Capital Gains Taxation," NBER Working Paper No. 2792, 2004. https://www.nber.org/reporter/spring04/taxpayer-behaviorand-government-policy

[39] Menoncin, F., Panteghini P., "Respective Capital Gains Taxation in the Real World," CESifo Working Paper Series 2674, 2009. https://ideas.repec.org/p/ces/ceswps/_2674.ht $\mathrm{ml}$

[40] Menoncin, F., Panteghini P., "Respective Capital Gains Taxation in the Real World," CESifo Working Paper Series
2674, 2009. https://ideas.repec.org/p/ces/ceswps/2674.ht $\mathrm{ml}$

[41] Menoncin, F., Panteghini P., "Respective Capital Gains Taxation in the Real World," CESifo Working Paper Series 2674, 2009. https://ideas.repec.org/p/ces/ceswps/_2674.ht $\mathrm{ml}$

[42] R. Epstein R., Henderson T., "Do Accounting Rules Matter? The Dangerous Allure of Mark to Market," Journal of Corporation Law, vol. 36, pp. 513-549, 2011. https://chicagounbound.uchicago.edu/cgi/viewcontent.cgi? article $=2340 \&$ context $=$ journal_articles

[43] Heaton J., Lucas D., McDonald R., "Is mark-to market accounting destabiliZIng? Analysis and implications for policy," Journal of Monetary Economics, vol. 57, no. 1, pp. 64-75, 2010. DOI:10.1016/j.jmoneco.2009.11.005

[44] Zee H., "Taxing the Financial Sector: Concepts, Issues and Practice," IMF Paper, pp. 45-56, 2004.DOI: https://doi.org/10.5089/9781589063167.071

[45] Laukkanen A., "Taxation of Investment Derivatives, " IBFD Publishing, 2007.http://unmarks.com/index.php?p=s how_detail\&id=82\&keywords=

[46] Zee H., "Taxing the Financial Sector: Concepts, Issues and Practice," IMF Paper, pp. 45-56, 2004.DOI: https://doi.org/10.5089/9781589063167.071

[47] Auerbach A., "Retrospective Capital Gains Taxation,' NBER Working Paper No. 2792, 2004 https://www.nber.org/reporter/spring04/taxpayer-behaviorand-government-policy

[48] OECD, "Hybrid Mismatch Arrangements: Tax Policy and Compliance Issues," OECD Publishing, pp. 1-27, 2012. https://www.oecd.org/ctp/aggressive/HYBRIDS_ENG_Fin al_October2012.pdf

[49] Mills L., Newberry K., "Firms' off-balance sheet and hybrid debt financing: evidence from their book-tax reporting differences," Journal of Accounting Res, vol. 43, no. 2, pp. 251-282, 2005. DOI: 10.1111/j.1475-679x.2005.00170.x

[50] Mills L., Newberry K., "Firms' off-balance sheet and hybrid debt financing: evidence from their book-tax reporting differences," Journal of Accounting Res, vol. 43, no. 2, pp. 251-282, 2005. DOI: 10.1111/j.1475-679x.2005.00170.x

[51] Huizinga H., L. Leaven and G. Nicodeme, "Capital structure and international debt shifting," Journal of Financial Economics, vol. 88, no. 1, pp. 80-118, 2008.

[52] Shaxson N., "Tackling Tax Havens: The billions attracted by tax havens do harm to sending and receiving nations alike," Finance and Development, vol. 56, no. 3, 2019. https://jia.sipa.columbia.edu/online-articles/how-tackle-tax -havens

[53] Vascega M., "Assessment of Taxes in Cross-Border Situations," EC Tax Review, vol. 20, no. 3, pp. 148-154, 2011.

[54] Gabert I., "DAC, Council Directive 2011/16/EU on Administrative Cooperation in the Field of Taxation," European Taxation, vol. 51, no. 8, pp. 342-347, 2011. 
[55] Helleiner E., "States and the Reemergence of Global Finance: From Bretton Woods to the 1990s," Cornell University Press, 1994.

[56] Ryner M. and Cafruny M., "The European Union and Global Capitalism: Origins, Development and Crisis," Palgrave Press, 2017.

[57] Wigan D., "Financialisation and Derivatives: Constructing an Artifice of Indifference," Competition and Change, pp. 157-172, 2009. DOI: 10.1179/102452909X417033

[58] Bryan D. and Rafferty M., "Capitalism with Derivatives: A Political Economy of FInancial Derivatives, Capital and Class," Palgrave Press, 2006.

[59] Dagan T., "International Tax Policy: Between Competition and Cooperation," Cambridge University Press, 2018.

[60] Johannesen N., "Tax avoidance with cross-border hybrid instruments," [2014] Journal of Public Economics, vol. 112, pp. 40-52, 2014. DOI: 10.1016/j.jpubeco.2014.01.011

[61] Hong Q., Smart M., "In praise of tax havens: international tax planning and foreign direct investment," European Economic Review, vol. 54, no. 5, pp. 82-95, 2010.

[62] Vella J., "The Asymmetrical Treatment of Debt and Equity Under UK Tax Law" [2011] in Arad Reisberg and Dan Prentice (eds), Corporate Finance Law: UK and EU Perspectives, Oxford University Press, pp. 361-392, 2011.

[63] Onileowo T. T., Muharam F. M., Family M. K., Saleh F. A., "The Nexus between Innovation and Competitive Advantage: A Conceptual Study," Universal Journal of Accounting and Finance, vol. 9, no. 3, pp. 352-361, 2021. DOI: 10.13189/ujaf.2021.090309

[64] Miller, C. and Tyger, A., "The Impact of a Financial Transaction Tax," Tax Foundation, January 2020. https://taxfoundation.org/financial-transaction-tax/

[65] A. Persaud, "Taxing transactions in financial derivatives: problems and solutions," International Capital, 2014. https://saludporderecho.org/wp-content/uploads/2014/09/T axing_Derivatives_Transactions_Persaud_Embargo_12091 4.pdf 